\title{
SOCIO-ECONOMIC DETERMINANTS OF PRODUCTION OF PRO-VITAMIN A CASSAVA VARIETIES BY FARMERS IN ETIM EKPO LOCAL GOVERNMENT AREA, AKWA IBOM STATE, NIGERIA
}

\author{
J. B. EFFIONG, G. B. EFFIONG AND U. A. UDO
}

(Received 20 October 2015; Revision Accepted 5 November 2015)

\begin{abstract}
This study assessed the socio-economic determinants of the production of Pro-vitamin A Cassava varieties by farmers in Etim Ekpo L.G.A., Akwa Ibom State, Nigeria. One hundred and fifty-eight (158) respondents were selected through a multistage sampling procedure. Field data were elicited with the use of questionnaire randomly distributed to the respondents. Data were analyzed with frequency, percentage, mean and multiple regression. The results revealed that majority of the respondents were females $(62.66 \%)$, married $(68.99 \%)$ and $30-50$ years $(72.15 \%)$. Results also indicated that Income $(T=2.21)$, Age $(T=1.93)$ Farm size $(T=1.92)$ Marital status $(T=1.29)$ and Labour $(T=6.30)$ are the socio-economic variables that influenced the production of pro - vitamin A cassava varieties. Pro - vitamin A cassava varieties mostly planted by the farmers are TMS 01/1412 (94.34\%), TMS 01/1368 (92.40\%), TMS 01/ 1371 $(68.35 \%)$, NR $03 / 0311(58-23 \%)$ other varieties of Cassava $(61.39 \%)$. It was recommended that essential rural development facilities should be provided for cassava farmers in the rural communities of Etim Ekpo L. G. A and Akwa Ibom State in general.
\end{abstract}

KEYWORDS: Socio-economic, production, Pro-vitamin A cassava, and varieties Etim Ekpo.

\section{INTRODUCTION}

Cassava is an important root crop widely grown by both male and female farmers in Nigeria (Ironkwe, Mbanaso and Ezebuiro, 2011). It is a robust crop able to withstand disease, drought and pests. It can grow on poor marginal soils and is thus cultivated and eaten where both poverty and malnutrition is widespread (www.harvestplus, 2013). Nigeria is currently the largest producer of Cassava in the world with annual output of over 34 million tones of tuberous roots. (Aroke, 2014) Cassava production has been increasing for the past 20 years in area cultivated and in yield per hectare. On average, the harvested land area was over 80 percent in the 1990s, and with renewed emphasis on its production by federal and state governments, cassava production has maintain a gradual rise (FAO, 2011). Cassava is important, not just as food crop but as major source of cash income for producing households, in comparison with other staples, it contributes positively to poverty alleviation by generating income for the largest number of households (Aroke, 2014). Vitamin A is an essential nutrient lacking in the diets of poor malnourished populations. Vitamin A deficiency retards growth, increases risk of disease, and can cause reproductive disorders. Improving Cassava production with ProVitamin A (Biofortification) could significantly improve nutrition and overall health, especially among poor communities (www.harvestplus, 2013).

Genetic improvement of cassava by natural selective breeding is a very promising first line intervention, newly improved provitamin A Cassava varieties with yellow roots have been released by the Nigerian government, stepping up efforts to tackle the problem of vitamin A deficiency especially in children (National Root Crop Research Institute NRCRI, 2011; Chiedozie, 2011; Effiong and Asikong) 2013. Provitamin A Cassava varieties help to reduce the incidence of vitamin A deficiency in the rural communities (Etuk and Umoh, 2014).

According to NRCRI (2013), Pro-vitamin A can repair immune system and vision that could cause blindness. Babatunde (2012) cited in Etuk and Umoh, (2014) noted that large components of vulnerable populations; women and children in areas where cassava consumption is high are at risk of vitamin A deficiency. Cassava is a staple food crop with worldwide distribution and serve as a fundamental energy source and food security for about 80 million people Worldwide (FAO, 2004). According to Ironkwe et al (2011), because of the significant contribution of cassava to food security and economic development of the country, the Federal Government of Nigeria embarked upon a number of programmes to boost its production. These include, Cassava Multiplication programmes, Root and Tuber expansion programmes and Pro-vitamin A cassava

J. B. Effiong, Department of Agricultural Extension and Rural Sociology, Faculty of Agriculture, Forestry and Wildlife Resources Management, University of Calabar, P.M.B. 1115, Calabar, Cross River State, Nigeria.

G. B. Effiong, Department of Agricultural Economics and Extension, Faculty of Agriculture, University of Uyo, Uyo, Akwa Ibom State, Nigeria.

U. A. Udo, Department of Agricultural Extension and Rural Sociology, Faculty of Agriculture, Forestry and Wildlife Resources Management, University of Calabar, P.M.B. 1115, Calabar, Cross River State, Nigeria. 
production technologies amongst others. Considering the importance of cassava as a traditional staple food in Nigeria, its productivity can be increased and sustained through efficient utilization of existing resources. According to Etuk et al (2014), vitamin A deficiency is widely prevalent in sub-saharan Africa, it affects almost $20 \%$ of pregnant women and about $30 \%$ of children under-five in Nigeria. This study will however help in various ways by strengthening extension-farmer linkage with research to facilitate the ongoing spread of Cultivars, Management practice, increase Pro-vitamin A Cassava production and enhance rural house hold income. Therefore massive production of pro-vitamin A cassava varieties are necessary in Etim Ekpo Local Government Area, Aka Ibom State and Nigeria in general.

\section{Objectives of the Study}

The major objective of this study was to determine the socio-economic determinants of production of pro-vitamin A cassava varieties by farmers in Etim Ekpo Local Government Area. However, the specific objectives were

1. to describe the socio-economic characteristics of cassava farmers in Etim Ekpo Local Government Area, Akwa Ibom State.

2. identify pro-vitamin $A$ cassava varieties available to farmers in the study area.

3. determine factors affecting the production of pro-vitamin A Cassava varieties in the study area.

\section{Hypothesis of the Study}

There is no significant relationship between socio-economic characteristics of the farmers and the production of pro-vitamin A cassava varieties in the study area.
Methodology

The study was conducted in Etim Ekpo Local Government Area of Akwa Ibom State, Nigeria. Etim Ekpo was created from the former Abak division, it is one of the Annang speaking area of Akwa Ibom State. It comprises of seventy villages and divided into five clans namely; Utu, Ikono, Obong, Uruk and Utu Annang. The area occupies a total land mass of about 25, 985 square kilometers with Utu Etim Ekpo town as its headquarters. Statistically, Etim Ekpo has a population of over 105, 418 people with 55, 771 males and 49, 647 females (National population census NPC, 2006). It is located $50 \mathrm{~km}$ from Uyo, the capital city of Akwa Ibom State. Etim Ekpo is bounded on the North by Essien Udim, South by Ukanafun, East by Abak and West by lka Local Government Areas. Climate is tropical and marked by dry and wet seasons. It has a mean annual rainfall of $2,200 \mathrm{~mm}$ with a daily mean temperature of $20^{\circ} \mathrm{c}$ to $31^{\circ} \mathrm{C}$ which favours cassava production. The early planting period is usually between February and March, while the late planting starts between September and October (Effiong and Effiong, 2015). The population of the study comprises all cassava farmers in the study area. Multistage sampling techniques were used in selecting the respondents.

At the first stage, three clans were randomly selected out of the five clans in the Local Government Area based on their degree of participation in cassava production. At the second stage, Utu, Obong and Uruk clans have twenty, seventeen and fifteen villages respectively out of which five percent were randomly selected from each, making four, three and two villages for the clans respectively. At the third stage, fifty-eight, fifty and fifty households respectively were randomly selected from each village. At the last stage, a farmer was selected from each household giving a sample size of one hundred and fifty eight (158) respondents used for the study of socio-economic determinants of production of Pro-vitamin A cassava varieties by farmers in Etim Ekpo Local Government Area, Akwa Ibom State as illustrated below; 
Etim Ekpo Local Government Area

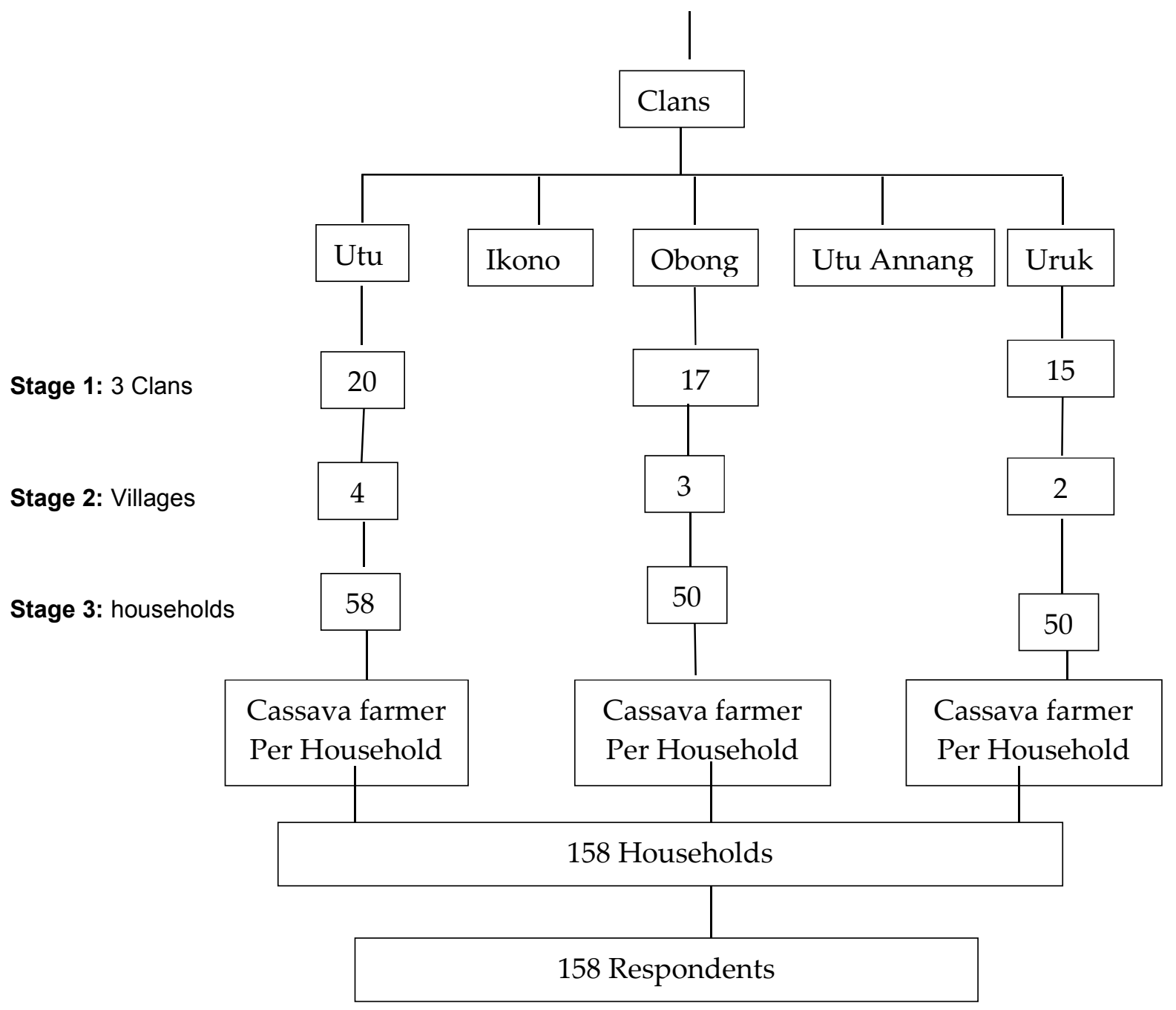

Fig 1: Illustration of sampling procedure for the study Source: Field Survey, 2014

Data for the study was collected through the use of questionnaire and interview schedule and analyzed with descriptive statistics such as frequencies and percentages. Inferential statistics used was the linear multiple regression analysis. 
RESULTS AND DISCUSSION

Table I: Distribution of Respondents according to their socio-economic characteristics.

\begin{tabular}{ll}
\hline Variables & Frequency (Percentage) \\
\hline Sex & $59(37.34)$ \\
Male & $99(62.66)$ \\
Female & \\
Marital Status & $109(68.99)$ \\
Married & $32(20.25)$ \\
Single & $6(3.80)$ \\
Divorced & $11(6.96)$ \\
Widow & \\
Age & $30(18.99)$ \\
Less than 30 years & $114(72.15)$ \\
30-50 years & $14(8.86)$ \\
Above 50years & \\
Level of Education & $9(5.70)$ \\
No formal Education & $30(18.99)$ \\
FSLC & $92(58.23)$ \\
SSCE & $17(10.76)$ \\
OND/NCE & $6(3.79)$ \\
HND/DEGREE & $4(2.54)$ \\
Others & \\
Family size & $52(32.91)$ \\
Less than 5 & $97(61.39)$ \\
5-10 & $9(5.70)$ \\
More than 10 & \\
Income & $5(3.16)$ \\
Less than N20,00 & $74(46.84)$ \\
N20,000 - N50,00 & $79(50.00)$ \\
Above N50,000 & \\
Source of Labour & $106(67.09)$ \\
Family labour & $35(22.15)$ \\
Hired labour & $12(7.59)$ \\
Cooperative labour & $3(1.90)$ \\
Mechanical (Tractors) & $2(1.27)$ \\
Others & $26(16.46)$ \\
Farm size in Hectare & $101(63.92)$ \\
Less than 1 & $19(12.03)$ \\
2-2 & $7(4.43)$ \\
3-4 & $5(3.16)$ \\
4 and above & \\
& \\
&
\end{tabular}

Source: Field survey, 2014

Socio-economic Characteristics of Respondents:

The table above showed that a substantial proportion of cassava farmers in Etim Ekpo Local Government Area were female $(62.66 \%)$, while $(37.74 \%)$ of them were males. The implication of this finding is that cassava production in the area was largely carried out by the women. This finding agreed with the findings of Effiong and Effiong (2015) that, women farmers in Akwa lbom State are largely involved in food crop production. The table also, showed that majority of the respondents were married $(68.99 \%)$. It also revealed that about $(20.25 \%)$ of the farmers were single and only $(3.80 \%)$ were divorced. This implied that cassava production in Etim Ekpo Local Government Area is frequently carried out by married people. This finding agreed with an earlier finding by Meroyi and Farinde (2011) that family level decision making process on crop production type might be high and valued in a study area. The table further showed that a good proportion of cassava farmers in the study area were within the age range of 30-50 years $(72.15 \%)$, while about $(18.99 \%)$ of them were below 30 years. The least number of respondents were those above 50 years of age and accounted for only (8.86\%) of the cassava farmers. The implication of this is that cassava production is carried out by active and productive population. This agreed with an earlier submission by Aroke (2014) that cassava production is largely carried out by people within the productive age of 25 years and above. The table showed that cassava farmers in Etim Ekpo L.G.A. utilized a wide range of source of labour supply, in particular, a substantial proportion of the farmers $(67.09 \%)$ used family labour, while about $(22.15 \%)$ used hired labour. This implies that since labour was majorly used, the farmers labour cost will be less as they may not need to hire more labour. 
Table 2: Distribution of Respondents based on type of pro-vitamin A cassava varieties planted.

\begin{tabular}{ll}
\hline Pro-vitamin A Cassava Varieties Planted & $\mathbf{F ~ ( \% )}$ \\
\hline TMS 01/1368 & $145(92.40)$ \\
TMS 01/1412 & $150(94.34)$ \\
TMS 01/1371 & $108(68.35)$ \\
NR 03/0311 & $92(58.23)$ \\
NR 03/0155 & $51(32.28)$ \\
Other varieties planted & $97(61.39)$ \\
\hline
\end{tabular}

Multiple responses recorded

Source: Field survey, 2014

Data in the table above showed that TMS 01/1412 with 150 frequency at $94.34 \%$ multiple responses was mostly planted by farmers in the study area. This variety according to Akwa Ibom State Ministry of Agriculture and Natural Resources AKMANR (2014) is reported to have broad adaptability to different environmental condition, high yielding and has high disease resistant ability. The Table also showed that about $(92.40 \%)$ planted TMS 01/1368 while $(68.35 \%),(58.23 \%)$, and (32.28\%) planted TMS 01/1371, NR 03/0311 and NR $03 / 0155$ respectively. These varieties are high in provitamin A but may not be environmentally friendly to Etim Ekpo Local Government Area and Akwa Ibom Agricultural Zones.

Table 3: Summary of factors affecting production of Pro-vitamin A cassava varieties in the study area

\begin{tabular}{ll}
\hline Variables & $\mathbf{F}(\%)$ \\
\hline Tribal preference for a particular variety & $145(91.77)$ \\
Level of Education & $103(65.20)$ \\
Religious factor & $60(38.00)$ \\
Environmental constraints & $73(46.20)$ \\
Market availability & $130(82.28)$ \\
Lack of Information & $115(72.80)$ \\
Land tenure pattern & $53(38.54)$ \\
Inadequate funds & $141(89.33)$ \\
\hline
\end{tabular}

Multiple responses recorded

Source: Field survey, 2014

About 91.77 percent of the respondents agreed that tribal preference for a particular variety handed to them by their ancestors had in one way or the other influence their ability to accept other varieties of cassava introduced to them by scientific discoveries. Detailed analysis as shown in the Table above revealed that majority $(89.33 \%)$ of the respondents indicated that inadequate funds was one of the numerous problems confronting them in an attempt to produce pro-vitamin A cassava varieties in the study area. This result agreed with the findings of Effiong (2013) that tribal sentiment and preference affects agricultural production. Also, $(38.54 \%)$ of the respondents claimed that the pattern of land tenure in the area resulting in unavailability of land for food crop production is a major factor affecting the production of Pro-vitamin A cassava varieties in the study

area.

Table 4: Linear multiple regression analysis on Socio-economic variables and the production of pro-vitamin A cassava varieties.

\begin{tabular}{lll}
\hline & Beta & T-value \\
\hline Constant & -1.8305 & -1.440 \\
Sex & 0.010 & 0.502 \\
Age & $0.792^{*}$ & 1.93 \\
Level of education & 0.003 & 0.02 \\
Income & $0.260^{*}$ & 2.21 \\
Labour & $0.640^{*}$ & 6.30 \\
Farm size & $0.424^{*}$ & 1.92 \\
Marital status & $0.790^{*}$ & 1.29 \\
Family size & $-0.875^{*}$ & 2.14 \\
\hline
\end{tabular}

Source: Field survey, 2014

Level of significance $=0.05$

$$
\begin{array}{cc}
\mathrm{R}^{2}= & 0.730 \\
\mathrm{~F}= & 6.21 \\
\mathrm{~T}-\text { tabulated } & 1.91
\end{array}
$$


Table 4, showed that there was significant relationship between Socio-economic variables and the production of pro-vitamin A cassava varieties. Socioeconomic characteristics such as Age $(T=1.93)$, Income $(T=2.21)$, Marital Status $(T=1.29)$, Farm size, ( $T=1.92)$, Family size $(T=0.14)$ and Labour $(T=6.30)$ were significant at $0.05 \%$ level of probability.

The T-values were however compared with the T-tabulated value of 1.91. Sex and level of education were however not significant. The aggregate influence $\left(R^{2}=0.73\right)$ of the selected independent variable is high enough because not less than five (5) of the variables were significant. The $\mathrm{R}^{2}$ value indicates that the significant independent variables could explain about 73.0 percent of the variation in the dependent variable in the study. The beta values in table four revealed that age, marital status and labour supply $(0.79 \%),(0.79 \%)$ and $(0.64) \%$ take the highest portion respectively, indicating that the Age, marital status and labour supply have significant influence on the production of provitamin A cassava varieties in the study area. This finding collaborates with the earlier findings of Effiong and Effiong, 2015 that farmers participate effectively in Agricultural production in their active age. Also, most family depend on family labour for agricultural production in the rural areas.

\section{CONCLUSION AND RECOMMENDATIONS}

The study revealed that some Socio-economic variables such as marital status, Age, Income, Farm size, and Labour supply were found to have positive and significant influence on the production of pro-vitamin A cassava varieties while family size had a negative coefficient and significant influence on Pro-vitamin $A$ cassava varieties. Pro-vitamin A cassava production was found to be inadequately influenced by educational level and sex of the farmers and was not given much attention. Cassava occupies prominent place in Nigeria's food crop needs because it adapts well to most ecological zones of the country. Cost of production is very low and can do well on moderately fertile soils. Apart from providing food for Man, Cassava now plays prominent role in livestock feed industry. Production of Pro-vitamin A cassava varieties are however affected by tribal preference for a particular variety $(91.77 \%)$, inadequate funds $(89.33 \%)$, lack of sales outlet (Market availability $82.28 \%)$ educational level of $(65.20 \%)$ amongst others. It should therefore be incumbent on government to encourage the production of Pro-vitamin A cassava by providing financial support, education of farmers through extension contacts and machines for mechanized operations by rural farmers in Etim Ekpo in particular and Akwa Ibom State in general.

Extension organizations should create more awareness on the production of pro-vitamin A cassava varieties. Loan facilities should be made available to small-scale farmers to improve on their quantity of production. Cassava marketing centres should be created in the rural areas to help pro-vitamin A cassava farmers sell their farm products early, easily and faster.

\section{REFERENCES}

Aroke, J., 2014. Assessment of Extension Adoption technologies by farmers in Biase L.G.A. Cross River State. MSC Theses Submitted to the University of Calabar, Calabar.

Akwa Ibom State Ministry of Agriculture and Natural Resources- Extension Bulletin AKMANR., 2014. "The Farmer" A publication of Ministry of Agriculture, Uyo Akwa Ibom State.

Babatunde, J., 2002. Journey to Consumption of Provitamin A Cassava varieties in Nigeria.

Chiedozie, E., 2011. Report on New Improved Cassava varieties released in Nigeria. Journal of Biology, Agriclture and Health Care. www, ilste.org,www.integratedbreeding.Nig/news .1.2.

Effiong, J. B., 2013. Prospects and Constraints of Indigenous Agricultural practices among Rural farmers in Itu L.G.A., Akwa Ibom State, Nigeria. Medwell Agricultural Journal Series 8, (I): 22-25.

Effiong, J. B and Asikong, A. B., 2013. Mid-term Assessment of the activities of Fadama III development project in Cross River State. Global Journal of Agriculture. 12, (1): 3-5.

Effiong, J. B and Effiong G. B., 2015. Adoption of Improved Rubber Production Technologies by Farmers in Akwa Ibom State, Nigeria. Global Journal of Agriculture 14, (1): 4-5.

Etuk, U. R and Umoh, I. U., 2014. Adoption Pattern of Pro-vitamin A Technology among farmers in Akwa Ibom State, Nigeria. Nigerian Journal of Agriculture, Food and Environment. 10, (4): 135138.

Food and Agriculture organization FAO., 2004. The state of Food insecurity in the World. Rome. www.FAO.org.

Food and Agriculture Organization FAO., 2010. Agriculture Food and Nutrition for Africa; A Resource book for Teachers of Agriculture. Rome.

Harvest Plus., 2013. Vitamin A Cassava; better crop and better Nutrition (www.harvest plus.org/content).

Ironkwe, A. C., Mbanaso, G. O and Ezebuiro, N. L., 2011. Gender Roles and Technical Efficiency of Farmers for sustainable Cassava production in Abia State, Nigeria. Nigerian Journal of Rural Sociology. 12, (2):

Meroyi, A. A and Farinde, A. J., 2011. Assessment of the relevance of Leventis Foundation School of Agriculture and Radio programme as information source to farmers in llesa Enclave of Osun State, Nigeria. In Proceedings of the $21^{\text {st }}$ 
Annual National Congress of the Nigerian Rural Sociological Association, held at University of Ibadan, $7^{\text {th }}-11^{\text {th }}$ October, 2012. 72-73.

National Root Crop Research Institute NRCRI., 2011. Annual report of new cassava varieties released in Nigeria. A publication of NRCRI, Umudike, Abia State, Nigeria. $5-11$.

National Root Crop Research Institute NRCRI., 2013. Annual report of New Cassava Varieties released in Nigeria. Publication of NRCRI, Abia State, Nigeria.
National Population Commission., (NPC 2006). National Population Census for 2006. NPC, Abuja. www.NPC.gov.ne. 